\title{
High Resolution Facies Record on Late Holocene Flood Plain Sediments from Lower Reaches of Narmada Valley, Western India
}

\author{
Prabhin Sukumaran ${ }^{1,4}$, Dhananjay A. Sant ${ }^{1}$, K. Krishnan $^{2}$ and Govindan Rangarajan ${ }^{3}$ \\ ${ }^{1}$ Department of Geology, Faculty of Science, ${ }^{2}$ Department of Archaeology and Ancient History, Faculty of Arts \\ The Maharaja Sayajirao University of Baroda, Vadodara - 390002 \\ ${ }^{3}$ Department of Mathematics, Indian Institute of Science, Bangalore - 560012 \\ ${ }^{4}$ Institute of Seismological Research, Gandhinagar - 382009 \\ Email: prabhins@gmail.com
}

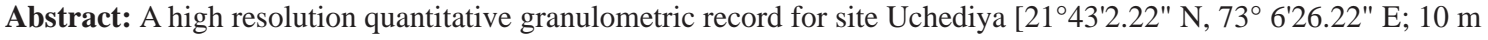
a. s. 1.] gives understanding towards accretion history of the late Holocene flood plain in the lower reaches of Narmada River. Two sediment facies (sandy and muddy) and seven subfacies (sandy subfacies: $\mathrm{St}_{\mathrm{MS}+\mathrm{FS}+\mathrm{CS}}, \mathrm{Sm}_{\mathrm{FS}+\mathrm{MS}}, \mathrm{Sl}_{\mathrm{FS}+\mathrm{VFS}}$, and $\mathrm{St}_{\mathrm{MS}+\mathrm{CS}}$; muddy subfacies: $\mathrm{Fm}_{\mathrm{SILT}+\mathrm{VFS}+\mathrm{FS},} \mathrm{Fm}_{\mathrm{SILT}+\mathrm{VFS}+\mathrm{FS}}(\mathrm{O})$ and $\left.\mathrm{Fm}_{\mathrm{SILT}+\mathrm{VFS}+\mathrm{FS}}(\mathrm{T})\right)$ are identified based on cluster analysis supplemented with sedimentary structures observed in field and other laboratory data. Changes in hydrodynamics are further deduced based on various sedimentological parameters and their ratios leading to arrive at a depositional model.
\end{abstract}

Keywords: Lower reaches of Narmada valley, Late Holocene, Sedimentology, Sediment facies, Hydrology.

\section{RATIONALE, STUDY AREA AND BACKGROUND}

Continental response to a climate change is best achieved through multi-faceted studies on various landforms in the river flood plains. The changes in both landforms and the sediment characteristics have long been used as an indication for climate change (Reid and Frostick, 1997; Nanson and Tooth, 1999; Knox, 2000; Macklin et al. 2002; Macklin and Lewin, 2003). Lower reaches of Narmada River (LrNR) expose a very conspicuous pair of landforms namely, the palaeobank extending from town Rajpardi in east towards the mouth of river Narmada in west, for almost $33 \mathrm{~km}$ (Bedi and Vaidyanadhan, 1982) and the late Holocene flood plain (chronology bracket from Raj and Yadava, 2009: 1950 \pm 90 to $1280 \pm 70 \mathrm{yrs}$ BP) that developed adjacent to palaeobank (Fig.1). The present study focuses on the late Holocene flood plain, along the present Narmada River. This river flows (on an average) $8 \mathrm{~m}$ below this late Holocene flood plain throughout most of the year except during monsoon flood periods, when the flood water submerges the Holocene surface and adjacent palaeobank becomes active. The majority of the surface is used for agriculture, whereas villages are located high above over palaeobank.

The LrNR has been investigated through various perspectives namely, general geomorphology (Wainwright, 1964; Allchin and Hegde, 1969; Gadekar et al. 1981; Bedi and Vaidyanadhan, 1982; Sant and Karanth, 1988; Ganapathi and Pandey, 1991; Sant and Karanth, 1993; Sant, 1999); Quaternary stratigraphy (Chamyal and Merh, 1992; Bhandari et al. 2005); volcanic ash (Raj, 2008); alluvial fans (Chamyal et al. 1994; Chamyal et al. 1997); neotectonics (Chamyal et al. 2002; Raj et al. 2003; Raj, 2007; Raj and Yadava, 2009) and radiocarbon chronology

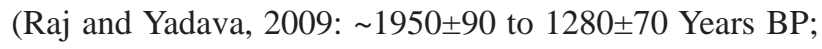
cal BP 1924 to cal BP 1172 for intercalated silty sandy and clay sequence near Uchediya village along bank of river Kaveri). However the late Holocene sedimentary sequence in this area lacks a systematic sedimentological analysis.

In the present paper we discuss high resolution granulometric data as well as various statistical parameters calculated from these records, supplemented with inputs from field (nature of facies contacts and sedimentary structures) and other laboratory data (foraminifera record) from a representative site Uchediya $\left[21^{\circ} 43^{\prime} 2.22^{\prime \prime} \mathrm{N}, 73^{\circ}\right.$ 6'26.22" E; $10 \mathrm{~m}$ a.s.1.] west of Kaveri River along the bank of River Narmada. The quantitative record is further used to identify sediment facies, depositional environment, hydrological characters and changes that occurred through sediments aggradation.

\section{GEOMORPHOLOGY}

The course of River Narmada downstream of the dam at 

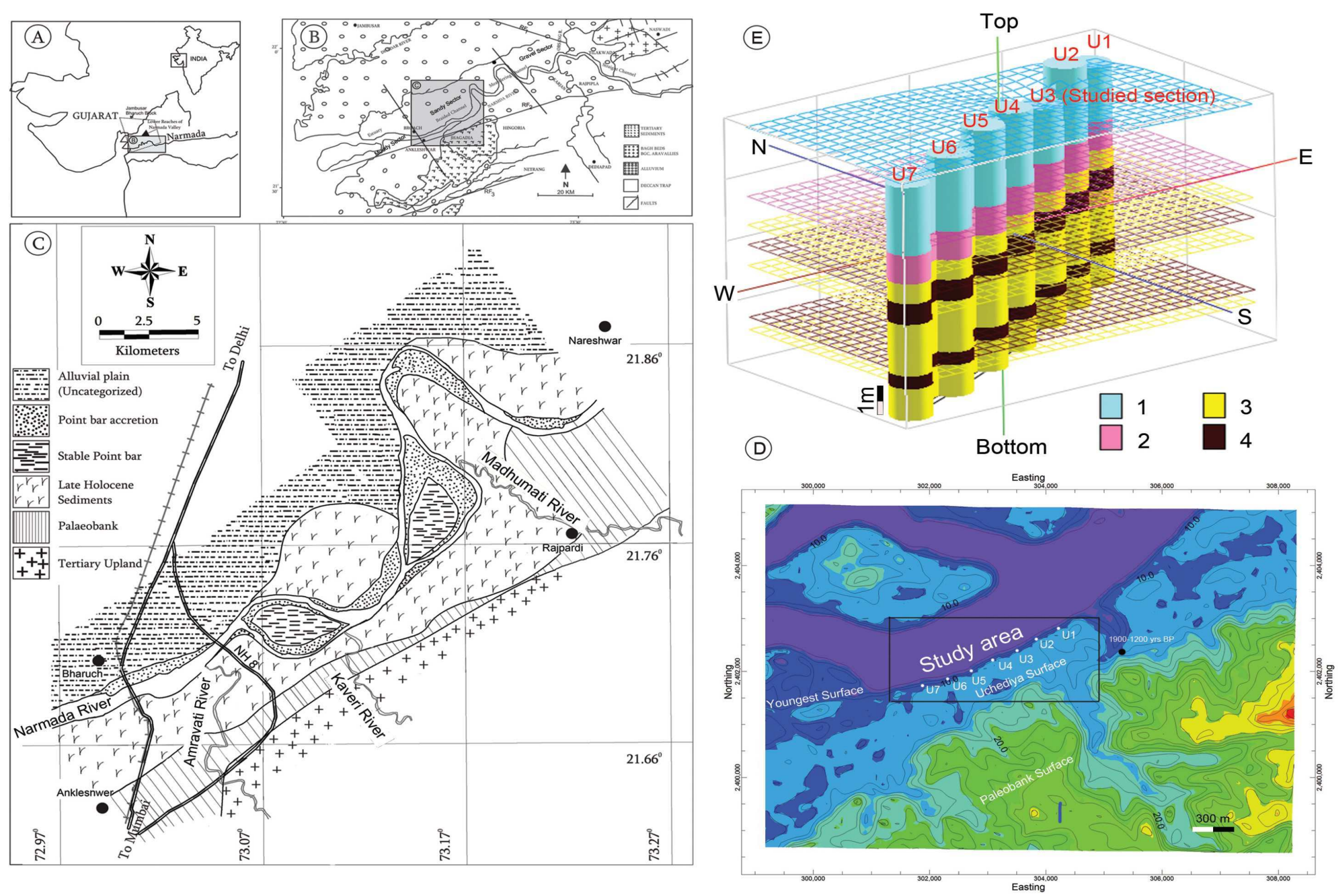

Fig.1. Geomorphology and location map of the study area. (A) Geographic location with reference to India; (B) Regional geology and structural features of Lower reaches of Narmada valley modified after Sant (1991); (C) Detailed geomorphology of the study area (modified after Bedi and Vaidhyanadhan, 1982); (D) Digital elevation model for the Late Holocene and palaeobank surfaces (U1 to U7 represent the sites of lateral mapping); (E) Lateral mapping of the Late Holocene sequence deciphering a near horizontal lithounits; wire line indicate the possible extension of the sediment contacts. 1,2, 3 and 4 indicates visually distinguishable sedimentary units. 
Kevadiya is identified as LrNR. The LrNR is divided into three segments based on dominance of present day channel sediments namely, gravelly channel (Kevadiya to Chanod), sandy channel (Chanod to Bharuch) and muddy channel (from Bharuch up to river mouth) (Fig.1B). The Palaeobank and late Holocene flood plain are the two well-developed landforms in the sandy sector and then extending into the muddy sector with diminishing elevation difference (Fig.1D). The late Holocene flood plain is flat and gently dips in the northerly direction. The plain is incised by transverse flowing Narmada tributaries (Madumati River, Kaveri River and Amravati River) (Fig.1C). These tributaries become defunct soon after they enter late Holocene flood plain that emerges across the palaeobank. The exposed section along these tributaries and river Narmada gives an opportunity to map the extension of sediments laterally (Fig.1E).

\section{METHODOLOGY}

A systematic survey was carried out over the late Holocene flood plain for a stretch of $2.4 \mathrm{~km}$ along river Narmada and $700 \mathrm{~m}$ transverse along river Kaveri (a tributary) covering an area of about 1.68 sq. km (Fig.1E). The surface detail of the landform was deciphered using digital elevation models supplemented with field checks and subsurface information was deciphered using a shallow seismic study (Sukumaran et al. 2011) that utilized ambient noise. A representative site Uchediya was selected along the channel of Narmada $\left(21^{\circ} 43^{\prime} 2.22^{\prime \prime} \mathrm{N}, 7^{\circ} 6^{\prime} 26.22^{\prime \prime} \mathrm{E} ; 10\right.$ $\mathrm{m}$ a.s.1.). High resolution studies were carried out in the cutopen trench over four benches across the $802 \mathrm{~cm}$ vertical profile. Each trench was approximately $200 \mathrm{~cm}$ in length and $50 \mathrm{~cm}$ in width; cut vertically along plumb line (Fig.2A). The trench was further dressed and cleaned so as to record field based sedimentological details (sedimentary facies, their transition and sedimentary structures) followed by continuous sampling at $2 \mathrm{~cm}$ interval. 401 samples were collected in 2 sets. One set packed in bottles was used for analysis, whereas the other set packed in aluminum foil in plastic bags was preserved as an undisturbed library sample.

Granulometric analysis was carried out for all 401 samples adopting the well-established sieve and pipette method (Folk, 1974; Syvitski, 2007; Cheetham et al. 2008). A hundred gram split of each sample was separated from the total sample by the method of conning and quartering. These samples were treated with dilute $\mathrm{HCl}$ and $6 \%$ hydrogen peroxide followed by washing with distilled water to remove carbonate and organic matter from the sample. After washing and cleaning, samples were subjected to wet sieving through $63 \mu \mathrm{m}$ sieve to separate silt and clay sediments. After separation, $>63 \mu \mathrm{m}$ and $<63 \mu \mathrm{m}$ particles were dried and packed in separate aluminum foils. More than $63 \mu \mathrm{m}$ sediments were then run in sieve shaker using sieves of $1000 \mu \mathrm{m}, 400 \mu \mathrm{m}, 250 \mu \mathrm{m}, 210 \mu \mathrm{m}, 149 \mu \mathrm{m}$, $125 \mu \mathrm{m}, 105 \mu \mathrm{m}, 88 \mu \mathrm{m}, 74 \mu \mathrm{m}$ and $63 \mu \mathrm{m}$. Each fraction was then collected separately and packed separately in air tight bags after being weighed in an electronic weighing balance.

Ten grams of processed $(<63 \mu \mathrm{m})$ sediments was taken from the wet sieved fraction of the total sediment for pipette analysis. These processed samples were added into the cylinder along with some amount of distilled water and $1 \mathrm{ml}$ of $10 \%$ cologne solution to make the total to $1000 \mathrm{ml}$. This was left overnight with stirring occasionally, so that the sediment disintegrated completely. The experimental cylinder was then put in a water bath to maintain an uniform temperature throughout the experiment. After stirring the cylinder vigorously for 2-3 minutes, pipette samples were drawn according to the time calculated (using Stock's law) for a given temperature. After calculation of each fraction, total weight of different fractions of each sample was normalized to 100 grams.

\section{SEDIMENT FACIES}

The sediment facies and their subfacies were analyzed using a statistical approach supplemented with sedimentological observation in field (largely following after Friend et al. 1986; Friend et al. 1979; Martinius, 2000). Grain size data of Uchediya sequence (401samples) was initially processed using cluster analysis. Each cluster was quantitatively determined, compared, evaluated and supplemented with field base details. Each cluster is referred to as sediment subfacies in this paper (Figs.3, 4 and 5). The nomenclature of sediment subfacies is based on the abundance of grain size and primary sedimentary structures in line with litho-facies classification after Martins (1965), Friedman (1967), Jackson (1975), Miall (1978, 1985), Friend et al. (1979), Friend et al. (1986) and Martinius (2000). In the present study, the $802 \mathrm{~cm}$ thick Uchediya sequence was classified into two broad sedimentary facies namely sandy facies (68\%) and muddy facies (32\%). Each of the facies was sub divided into subfacies based on cluster analysis of granulometirc data. The sediment subfacies were supplemented with other supporting records on composition and micro faunal assemblages at certain depths to resolve intricacies within subfacies.

\section{Sandy Facies}

The sandy facies is the most dominant facies $(68 \%)$ 

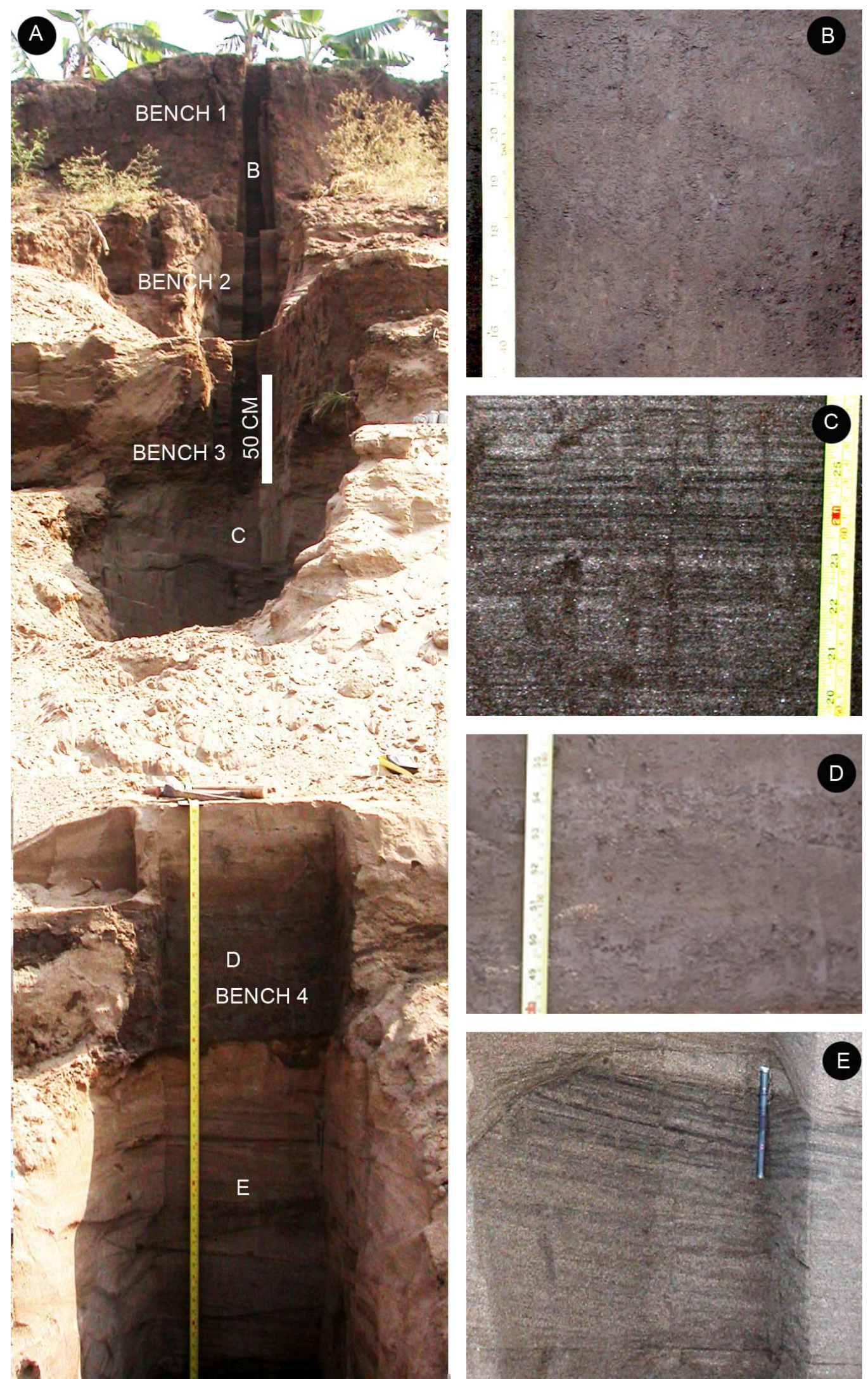

Fig.2. Field photographs showing (A) trench section and sedimentary structures. (B) Massive fine facies $\left(\operatorname{Fm}_{\mathrm{SILT}+\mathrm{VFS}}(\mathrm{O})\right)$, (C) Laminated sand facies $\left(\mathrm{Sl}_{\mathrm{FS}+\mathrm{VFS}}\right)$, (D) Massive Fine $\left(\mathrm{Fm}_{\mathrm{SILT}+\mathrm{VFS}}(\mathrm{T})\right)$ and $(\mathbf{E})$ Trough cross bedded sand facies $\left(\mathrm{St}_{\mathrm{MS}+\mathrm{CS}}\right)$. 


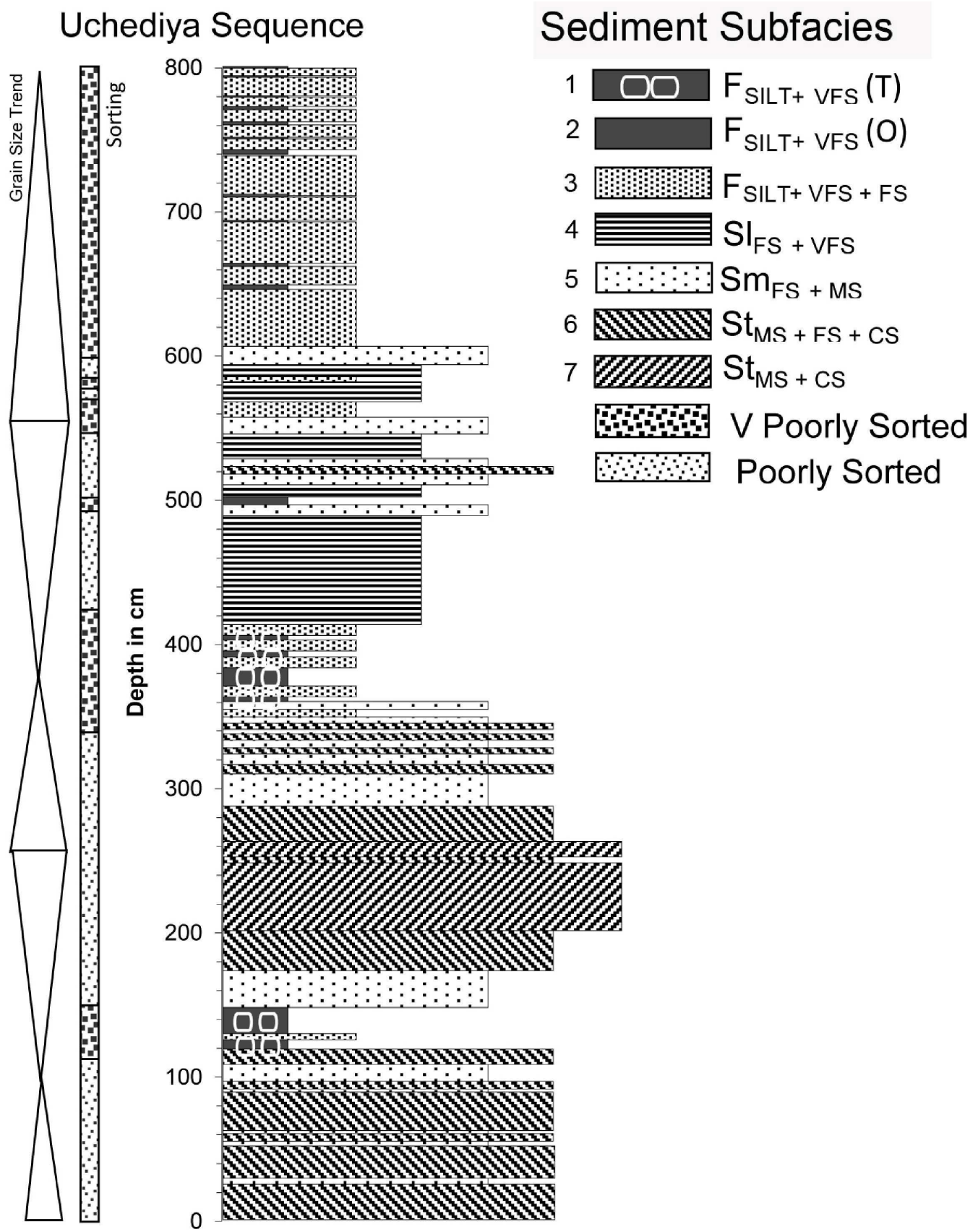

Fig.3. Litholog of Uchediya sequence showing different sedimentary subfacies and their associations.

exposed along the Uchediya sequence. This facies was inferred based on data from 247 samples. The sandy facies shows both laminae and trough-shaped cross bedding structures (Fig.2E). The sandy facies is further subdivided into four subfacies namely, $\mathrm{St}_{\mathrm{MS}+\mathrm{FS}+\mathrm{CS}}(32 \%), \mathrm{Sm}_{\mathrm{FS}+\mathrm{MS}}(29 \%)$ $\mathrm{Sl}_{\mathrm{FS}+\mathrm{VFS}}(26 \%)$, and $\mathrm{St}_{\mathrm{MS}+\mathrm{CS}}(13 \%)$. where the notation $\mathrm{Sl}$ refers to laminated sand; Sm to massive and St to troughshaped cross bedded components and the subscripts represent grain size (fine sand, very fine sand, medium sand an coarse sand). Overall, the sandy facies is poorly sorted (sorting ranges from 1.26 to 2 ) and show modality from bimodal to unimodal distribution.

$\mathrm{St}_{\mathrm{MS}+\mathrm{FS}+\mathrm{CS}}$ subfacies (10YR 5/4 to 10YR 4/3) are decoded by analyzing around 80 samples. The subfacies constitutes $32 \%$ of total sandy facies (Fig.4A). The subfacies show trough-shaped cross bedding with basalt pebbles seen occasionally along the trough cross. This subfacies is seen prominently in the lower portion of the sequence from the base to $120 \mathrm{~cm}$. The high resolution analysis shows that the $\mathrm{St}_{\mathrm{MS}+\mathrm{FS}+\mathrm{CS}}$ subfacies is sub divided into a number of units by 

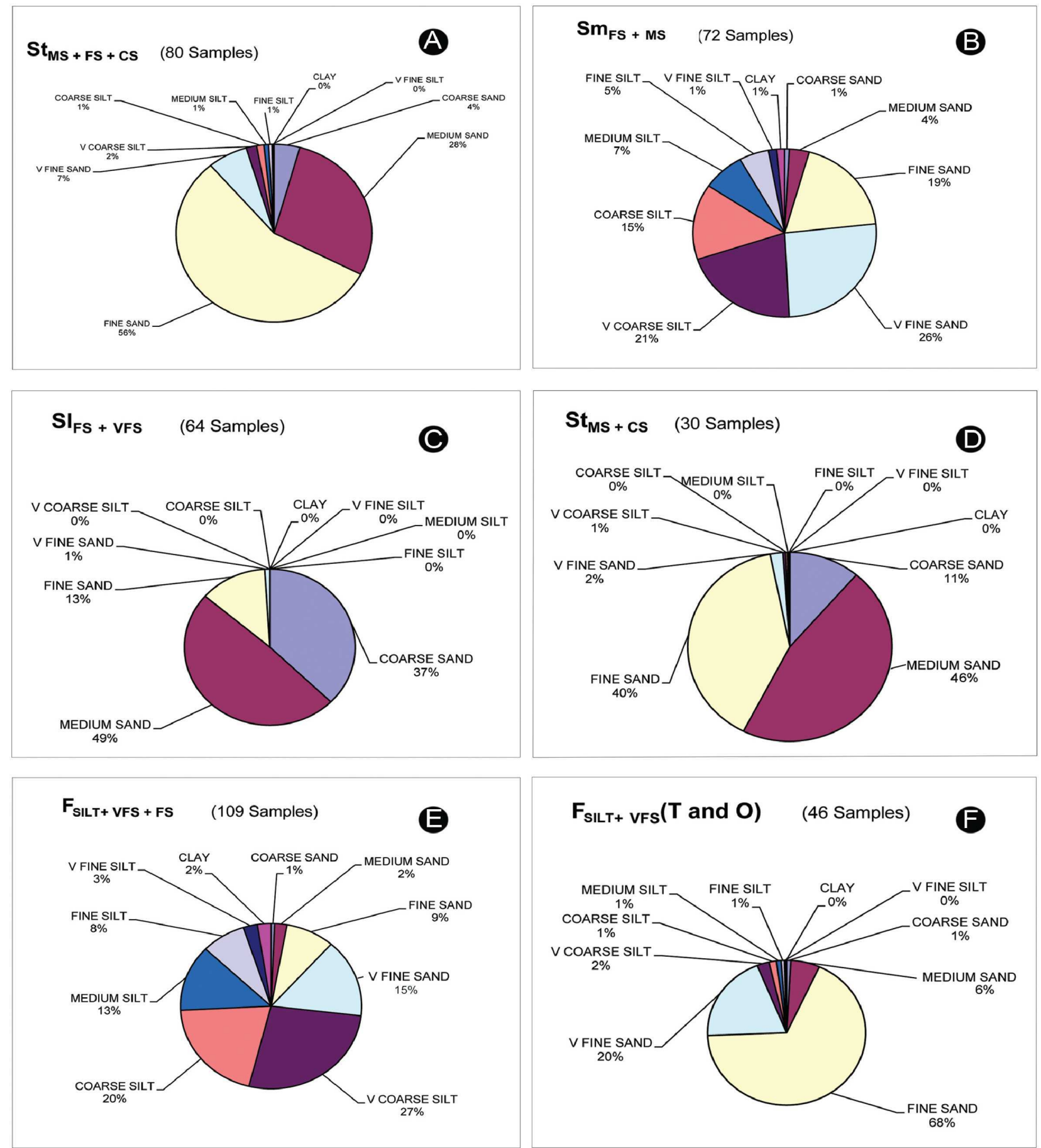

Fig.4. Pie diagram showing average values of sand, silt and clay percentage variation in each sedimentary subfacies.

intercalation of thin (few centimeters to $10 \mathrm{~cm}$ ) units of $\mathrm{St}_{\mathrm{FS}+\mathrm{MS}}$ subfacies and thick $(50 \mathrm{~cm})$ units of $\mathrm{St}_{\mathrm{MS}}+\mathrm{CS}$ subfacies. $\mathrm{St}_{\mathrm{MS}+\mathrm{FS}+\mathrm{CS}}$ subfacies are moderately well sorted showing unimodal, symmetrical and platykurtic distribution.

$\mathrm{Sm}_{\mathrm{FS}+\mathrm{MS}}$ subfacies (10YR 5/4 to 10YR 3/3) was inferred based on analysis of 72 samples and comprises $29 \%$ of sandy facies (Fig.4B). $\mathrm{Sm}_{\mathrm{FS}+\mathrm{MS}}$ subfacies are massive in nature and occur as an intercalating suite from base of the sequence up to $210 \mathrm{~cm}$ in the sequence. The facies become prominent in the range $150 \mathrm{~cm}$ to $168 \mathrm{~cm}$ and $290 \mathrm{~cm}$ to $310 \mathrm{~cm}$ from the base. Sediment units with $\mathrm{Sm}_{\mathrm{FS}+\mathrm{MS}}$ subfacies vary in thickness from a few centimeters to a maximum of $20 \mathrm{~cm}$. $\mathrm{Sm}_{\mathrm{FS}+\mathrm{MS}}$ subfacies are moderately sorted, showing 


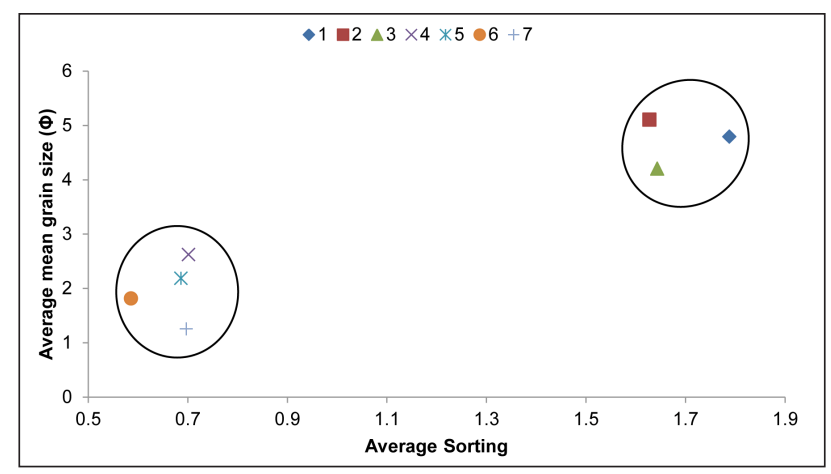

Fig.5. Plot of average sorting against averaged mean grain size of individual facies clearly shows clustering of two groups. Numbers 1 to 7 indicate the facies code as in Fig.3, Fig.4 and in additional material (Table 1).

unimodal, fine skewed and very leptokurtic distribution.

$\mathrm{Sl}_{\mathrm{FS}+\mathrm{VFS}}$ subfacies was inferred from analysis of 64 samples and comprises $26 \%$ of the sandy facies (Fig.4C). $\mathrm{Sl}_{\mathrm{FS}+\mathrm{VFS}}$ subfacies (10YR 5/4 to 10YR 4/5) are laminated and is seen restricted to the central portion of the sequence between $415 \mathrm{~cm}$ to $485 \mathrm{~cm}$. The subfacies also occurs as an intercalating suite alternate with its coarser equivalents from depth of $500 \mathrm{~cm}$ to $590 \mathrm{~cm}$. Sl $\mathrm{FS}_{\mathrm{FFS}}$ subfacies are moderately sorted showing bimodal nature skewed towards very fine classes $(80 \%)$ and leptokurtic $(61 \%)$.

$\mathrm{St}_{\mathrm{MS}+\mathrm{CS}}$ subfacies (10YR 5/4 to 10YR 4/3) was inferred from analysis of 30 samples respectively and comprises $13 \%$ of sandy facies (Fig.4D). $\mathrm{St}_{\mathrm{MS}+\mathrm{CS}}$ subfacies also shows trough-shaped cross bedding identified occurring within the $\mathrm{St}_{\mathrm{MS}+\mathrm{FS}+\mathrm{CS}}$ subfacies as a coarser fraction from $200 \mathrm{~cm}$ to $245 \mathrm{~cm}$. St ${ }_{\mathrm{MS}+\mathrm{CS}}$ subfacies differs from St ${ }_{\mathrm{MS}+\mathrm{FS}+\mathrm{CS}}$ subfacies in that it has a very platykurtic distribution curve.

\section{Muddy Facies}

The muddy facies are the second dominant facies (32\%) exposed along the Uchediya sequence. The facies was inferred based on data from 154 samples. The muddy facies shows both massive and laminated components. Overall the muddy facies are very poorly sorted (sorting ranges from 3.1 to 3.3). Based on the quantitative analysis of grain size data and association of primary structures, the muddy facies is further subdivided into two subfacies namely, $\mathrm{Fm}_{\mathrm{SILT}+\mathrm{VFS}}$ and $\mathrm{Fl}_{\mathrm{SILT}+\mathrm{VFS}+\mathrm{FS}}$ where Fm stands for massive muddy facies; Fl for laminated muddy facies; and subscripts represent dominance of grain size (silt, very fine sand and fine sand). Fm $_{\text {SILT+VFS+FS }}$ facies are poorly sorted showing bimodal to trimodal very fine skewed, platykurtic distribution. However the facies can be subdivided into Fm SILT+VFS $(\mathrm{O})$ and $\mathrm{Fm}_{\text {SILT+VFS }}(\mathrm{T})$ subfacies based on the presence $(\mathrm{T})$ or absence $(\mathrm{O})$ of microfossil assemblage at different levels (Sukumaran et al. accepted).

$\mathrm{Fm}_{\text {SILT+VFS+FS }}$ subfacies (10YR 4/4 to 10YR 4/3) was inferred from analysis of 109 samples respectively (Fig.4E) comprising $71 \%$ of the muddy facies. The $\mathrm{Fm}_{\mathrm{SILT}+\mathrm{VFS}+\mathrm{FS}}$ subfacies dominates in the sequence from $605 \mathrm{~cm}$ to $802 \mathrm{~cm}$ (top). A single unit varies from a maximum of $35 \mathrm{~cm}$ to a few centimeters. The subfacies unit thins consistently towards the top

$\mathrm{Fm}_{\text {SILT+VFS }}$ subfacies (10YR 4/4 to $10 \mathrm{YR} 4 / 3$ ) was decoded from analysis of 46 samples comprising $29 \%$ of muddy facies (Fig.4F). $\mathrm{Fm}_{\text {SILT+VFS }}$ subfacies units are well developed at depths from $120 \mathrm{~cm}$ to $145 \mathrm{~cm}, 360 \mathrm{~cm}$ to $410 \mathrm{~cm}, 495 \mathrm{~cm}$ to $500 \mathrm{~cm}$ and $605 \mathrm{~cm}$ to $802 \mathrm{~cm}$. Fm SILT+VFS subfacies occur as a thin intercalating unit with $\mathrm{Fm}_{\text {SILT+VFS }+\mathrm{FS}}$ subfacies from $605 \mathrm{~cm}$ to $802 \mathrm{~cm}$ and vice versa at depths between $120 \mathrm{~cm}$ to $145 \mathrm{~cm}$ and $360 \mathrm{~cm}$ to $410 \mathrm{~cm}$. Based on the presence or absence of foraminiferal assemblages we further classify $\mathrm{Fm}_{\mathrm{SILT}+\mathrm{VFS}+\mathrm{FS}}$ subfacies intoFm $\mathrm{SILT}+\mathrm{VFS}+\mathrm{FS}(\mathrm{O})$ and $\mathrm{Fm}_{\mathrm{SILT}+\mathrm{VFS}+\mathrm{FS}}(\mathrm{T})$ representing overbank and tidal conditions respectively.

\section{Palaeohydrology}

The sedimentary facies are represented by a suite of samples with similar textural characteristics. The textural

Table 1. Equations and terminologies used in the present paper

\begin{tabular}{|c|c|c|c|c|c|c|}
\hline Mean & \multicolumn{2}{|c|}{ Sorting $\left(\sigma_{1}\right)$} & \multicolumn{2}{|c|}{ Skewness $\left(\mathrm{Sk}_{1}\right)$} & \multicolumn{2}{|c|}{ Kurtosis $\left(\mathrm{K}_{\mathrm{G}}\right)$} \\
\hline \multirow{8}{*}{$\frac{\Phi 16+\Phi 50+\Phi 84}{3}$} & \multicolumn{2}{|c|}{$\frac{\Phi 16+\Phi 50+\Phi 84}{3}$} & \multicolumn{2}{|c|}{$\frac{\Phi 16+\Phi 84-2 \Phi 50}{2(\Phi 84-\Phi 16)}+\frac{\Phi 5+\Phi 95-2 \Phi 50}{2(\Phi 95-\Phi 5)}$} & \multicolumn{2}{|c|}{$\frac{\phi 95-\Phi 5}{2.44(\Phi 75-\Phi 25)}$} \\
\hline & Very well sorted & $<0-3.5$ & $\begin{array}{l}\text { Very fine } \\
\text { skewed }\end{array}$ & +0.3 to +1.0 & Very platykurtic & $<0.67$ \\
\hline & Well sorted & $0.35-0.50$ & Fine skewed & +1.0 to +0.3 & Platykurtic & $0.67-0.90$ \\
\hline & $\begin{array}{l}\text { Moderately well } \\
\text { sorted }\end{array}$ & $0.5-0.70$ & Symmetrical & +0.1 to -0.1 & Mesokurtic & $0.90-1.11$ \\
\hline & Moderately sorted & $0.70-1.00$ & Coarse skewed & -0.1 to -0.3 & Leptokurtic & $1.11-1.50$ \\
\hline & Poorly sorted & $1.0-2.00$ & $\begin{array}{l}\text { Very coarse } \\
\text { skewed }\end{array}$ & -0.3 to -1.0 & Very leptokurtic & $1.50-3.00$ \\
\hline & Very poorly sorted & $2.00-4.00$ & & & $\begin{array}{l}\text { Extremely } \\
\text { leptokurtic }\end{array}$ & $>3.00$ \\
\hline & $\begin{array}{l}\text { Extremely poorly } \\
\text { sorted }\end{array}$ & $>4$ & & & & \\
\hline
\end{tabular}


parameters for 401 samples (additional material Table 1; can be requested from the author) were determined using GRADISTAT v6 statistical package (Blott and Pye, 2001) using descriptive terminology for the size distribution after Friedman and Sanders, (1978) and the equations by original Folk and Ward (1957; Table 1). The grain size distribution in a sedimentary sequence gives quantitative textural characteristic for suites of facies. Various statistical parameters further capture the mechanism of sediment transport, the environment of deposition and its changes (Krumbein, 1934; Passega, 1964; Sahu, 1964; Folk, 1966; Friedman, 1967; Doeglas, 1968; Visher, 1969; Guerzoni et al, 1996; Pandey et al. 2002; Richard et al. 2005; Purkait, 2006; Bartholdy et al. 2007; Ren and Packman, 2007; Cheetham et al. 2008; Goossens, 2008; Poizot et al. 2008; Brandono et al. 2009; Buscombe and Masselink, 2009; Citterio and Piegay, 2009; Oldfield et al. 2009; Hajek et al. 2010).

In this section, we discuss and synthesize various such statistical parameters viz., mean, overall sorting, sorting within weight percentage of tails of fines ( $4 \phi$ and finer), kurtosis and skewness after Tenner (2007b). These are further plotted on bivariate diagrams for suitable interpretation. These diagrams capture hydrodynamics, sediment supply, trapping and other dynamical conditions. We use various diagrams to differentiate transporting agencies, transitions from one agency to another, change in energy conditions, and sediment contribution from outside systems. In view of the bimodal and polymodal sediments in the different facies, the statistical parameters were used only for the relative variation of the sediment characteristics.

\section{Bivariate Plots}

The plot of mean phi sizes verses weight percentage for $<3 \phi(0.125 \mu \mathrm{m})$ sediments (Fig.6A) is similar to segmented cumulative frequency curve, in which each distinct facies is transported by a particular mechanism such as suspension load (muddy facies); saltation (muddy and sandy facies) and traction (sandy facies). The plot show systematic transition of facies from leading, flat upper segment to central steeper segment to trailing flat segment. $\mathrm{Fm}_{\mathrm{SILT}+\mathrm{VFS}}(\mathrm{T})$ that leads the upper segment is followed by $\mathrm{Fm}_{\mathrm{SILT}+\mathrm{VFS}}(\mathrm{O})$ suggesting that subfacies were deposited under the suspension mode. The subfacies $\mathrm{Fm}_{\mathrm{SILT}+\mathrm{VFS}+\mathrm{FS}}$, falls at the transition of upper and steeper segment of the $S$ curve showing that at least part of subfacies were deposited through suspension and saltation. $\mathrm{Sl}_{\mathrm{FS}+\mathrm{VFS}}$, and $\mathrm{Sm}_{\mathrm{FS}+\mathrm{MS}}$, fall along the bottom portion of steeper segment suggesting that at least part of the sediment was deposited through saltation and traction. $\mathrm{St}_{\mathrm{MS}+\mathrm{FS}+\mathrm{CS}}$ and $\mathrm{St}_{\mathrm{MS}+\mathrm{CS}}$ fall along the trailing segment indicating sediment transportation under traction. The plot clearly shows the relationship between subfacies and mode of transport and thereby energy conditions at the time of deposition.
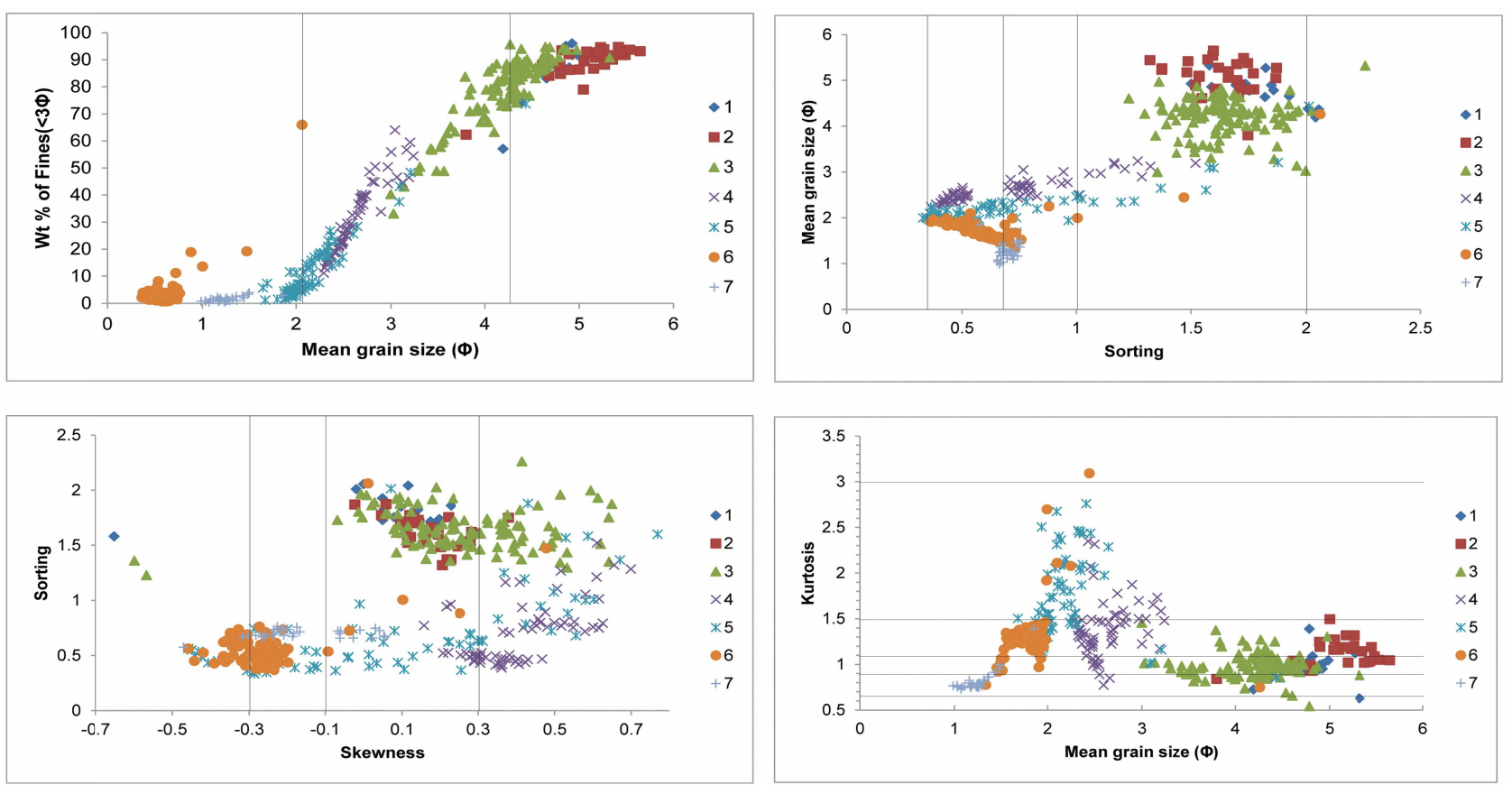

Fig.6. Bivariate plots of 401 samples used for the characterization of sediments. Numbers 1 to 7 indicate the facies code as in Fig.3, Fig.4 and additional material (Table 1). 
The plot between standard deviation in the grain size (sorting) and mean grain size (Fig.6B) differentiates muddy and sandy facies. It shows that compared to sandy facies, muddy facies are poorly to very poorly sorted. Part of subfacies $\mathrm{Sm}_{\mathrm{FS}+\mathrm{MS}}$ and $\mathrm{Sl}_{\mathrm{FS}+\mathrm{VFS}}$ falls in the transition region (moderate to poor sorting) between muddy facies and $\mathrm{St}_{\mathrm{MS}+\mathrm{FS}+\mathrm{CS}}$ and $\mathrm{St}_{\mathrm{MS}+\mathrm{CS}}$ subfacies. Similarly the plot of skewness (degree of asymmetry of a frequency) with standard deviation (sorting) clearly differentiates muddy and sandy facies as well as partially differentiates $\mathrm{Sl}_{\mathrm{FS}+\mathrm{VFS}}$, $\mathrm{Sm}_{\mathrm{FS}+\mathrm{MS}}, \mathrm{St}_{\mathrm{MS}+\mathrm{FS}+\mathrm{CS}}$ and $\mathrm{St}_{\mathrm{MS}+\mathrm{CS}}$ subfacies (Fig.6C).

A plot of mean grain size with kurtosis (degree of peakedness) also differentiates between the discussed sediment subfacies. The plot is able to distinguish parts of $\mathrm{Sm}_{\mathrm{FS}+\mathrm{MS}}$, and $\mathrm{Sl}_{\mathrm{FS}+\mathrm{VFS}}$ that show very leptokrutic distribution where they are extremely peaked having better sorting at centre then at the tails (Fig.6D).

\section{Other Plots}

The other five statistical parameters that we considered are difference in standard deviation (S1-S2), difference in kurtosis (K1-K2), mean/ kurtosis ratio (M/K), 1/kurtosis (1/ $\mathrm{K})$, standard deviation/kurtosis $(\mathrm{S} / \mathrm{K})$. Plotting these parameters against the depth (Fig.7) captures the time line (bottom, oldest; top, youngest) suggesting changes at the time of deposition (Tenner, 2007a).

The plot of S1-S2 with depth suggests distinct changes at $120 \mathrm{~cm}, 145 \mathrm{~cm}, 360 \mathrm{~cm}, 410 \mathrm{~cm}, 495 \mathrm{~cm}, 565 \mathrm{~cm}, 585 \mathrm{~cm}$, $605 \mathrm{~cm}$. Additionally, K1-K2 plot identifies changes at $310 \mathrm{~cm}$ and $330 \mathrm{~cm}$. Above $605 \mathrm{~cm} / 610 \mathrm{~cm}$ the sequence identifies 3-5 minor changes. These relative changes correlate with sediment facies contacts.

The plots of $\mathrm{M} / \mathrm{K}, \mathrm{S} / \mathrm{K}, 1 / \mathrm{K}$ signify relative change as well as relative elevation (higher or lower topography) at the time of deposition of sediments. The $\mathrm{M} / \mathrm{K}$ ratio suggests $\mathrm{St}_{\mathrm{MS}+\mathrm{FS}+\mathrm{CS}}$ subfacies (Fig.7; from 0 to $120 \mathrm{~cm}$ ), $\mathrm{St}_{\mathrm{MS}+\mathrm{FS}+\mathrm{CS}}$ subfacies and $\mathrm{St}_{\mathrm{MS}+\mathrm{CS}}$ subfacies (Fig.7; from $145 \mathrm{~cm}$ to $350 \mathrm{~cm}$ ) that was deposited at lower elevation. On the other hand, $\mathrm{Fm}_{\mathrm{SILT}+\mathrm{VFS}}(\mathrm{T}$ ) subfacies (from $120 \mathrm{~cm}$ to $145 \mathrm{~cm}$ and $365 \mathrm{~cm}$ ) and $\mathrm{Fm}_{\mathrm{SILT}+\mathrm{VFS}}(\mathrm{O})$ subfacies along with $\mathrm{Fm}_{\text {SILT+VFS+FS }}$ subfacies were deposited above $610 \mathrm{~cm}$ at a relatively higher elevation within the channel. The subfacies $\mathrm{Sm}_{\mathrm{FS}+\mathrm{MS}}$ and $\mathrm{Sl}_{\mathrm{FS}+\mathrm{VFS}}$ that dominate from $410 \mathrm{~cm}$ to $600 \mathrm{~cm}$ occur at a transition elevation compared to the other discussed sediment facies. The ratios $\mathrm{S} / \mathrm{K}$ and $1 / \mathrm{K}$ further distinguish between $\mathrm{St}_{\mathrm{MS}+\mathrm{FS}+\mathrm{CS}}$ subfacies and $\mathrm{St}_{\mathrm{MS}+\mathrm{CS}}$ subfacies suggesting that $\mathrm{St}_{\mathrm{MS}+\mathrm{CS}}$ subfacies were deposited at a relatively higher elevation than $\mathrm{St}_{\mathrm{MS}+\mathrm{FS}+\mathrm{CS}}$ subfacies. Possibly, the $\mathrm{St}_{\mathrm{MS}+\mathrm{CS}}$ subfacies represent accumulation of coarser facies during high energy condition or due to removal of finer sand under high energy conditions.

\section{Depositional Model for Uchediya Sequence}

The late Holocene sediment sequence (802 cm thick) under present study, along the southern bank of Narmada, west of Kaveri River, near village Uchediya represents a flood plain, the most conspicuous landform that gets submerged in the monsoon season during floods. The sequence comprises suites of seven subfacies that intercalate each other. The suites of subfacies are primarily inferred

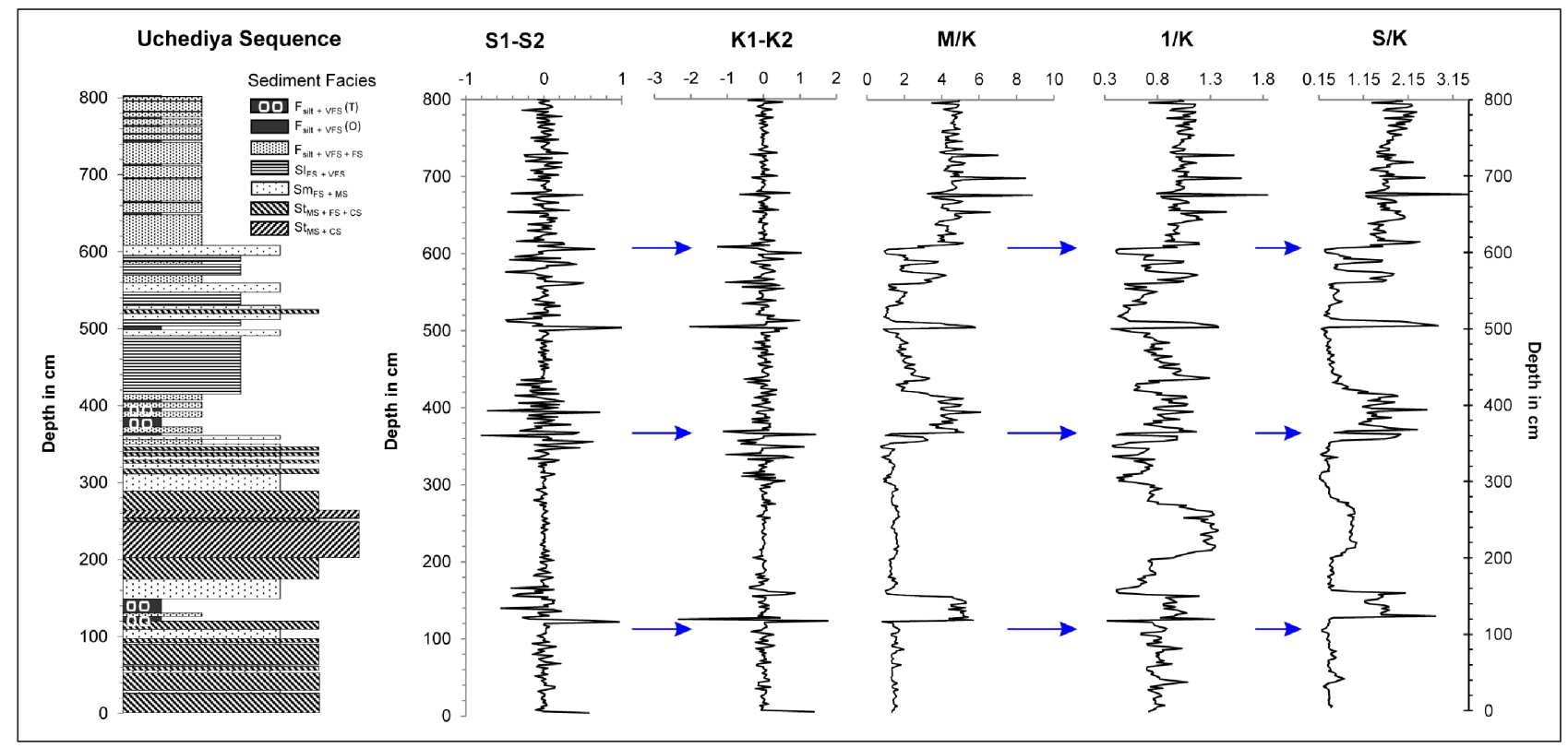

Fig.7. Other plots and its relation to individual facies in a vertical sequence. See text for details. 
applying cluster analysis to high resolution granulometric record supplemented with field sedimentological data at same resolution. The subfacies are further distinguished along bivarient asserting hydrodynamics. We plot ratios of few statistical parameters along depth to decipher relative changes and position during deposition. The depositional model for a flood plain is inferred in various phases.

The conditions prior to initiation of sediment deposition are inferred from plots of $\mathrm{M} / \mathrm{K}, \mathrm{S} / \mathrm{K}$ and $1 / \mathrm{K}$. The plots suggest the sediments were deposited at relatively lower elevation compared to overlaying $\mathrm{Fm}_{\mathrm{SILT}+\mathrm{VFS}}(\mathrm{T})$. We infer that the $\mathrm{St}_{\mathrm{MS}+\mathrm{FS}+\mathrm{CS}}$ subfacies were deposited in a shallow channel environment. Cross trough structures and pebbles embedded in them suggest that the sediment was transported under traction as bed load. The shift in the thalweg line exposed the channel bed. High tidal influx deposited $\mathrm{Fm}_{\text {SILT+VFS }}(\mathrm{T})$ subfacies with a sharp contact to the adjacent previously deposited channel facies. Further changes in channel reinstalled prior channel conditions. Sandwiching of $\mathrm{St}_{\mathrm{MS}+\mathrm{CS}}$ subfacies within $\mathrm{St}_{\mathrm{MS}+\mathrm{FS}+\mathrm{CS}}$ subfacies suggests accumulation of coarser sediment or erosion of finer sediment under flood conditions. Shift in thalweg line changes the permanent channel away from the present site of deposit. Intercalation of $\mathrm{Fm}_{\mathrm{SILT}+\mathrm{VFS}}(\mathrm{T})$ and Fm $\mathrm{SILT}+\mathrm{VFS}+\mathrm{FS}$ shows mixed depositional environment such as tidal and overbank flood deposits. Further aggradations resulted in a prominent point bar depositing $\mathrm{Sl}_{\mathrm{FS}+\mathrm{VFS}}$ subfacies. Interaction of $\mathrm{Fm}_{\mathrm{SILT}+\mathrm{VFS}}(\mathrm{O}), \mathrm{Sl}_{\mathrm{FS}+\mathrm{VFS}}$ subfacies and $\mathrm{Sm}_{\mathrm{FS}+\mathrm{MS}}$ subfacies thereafter suggest point bar accretion and stabilization. Finally the point bar bounded the southern bank of channel during non-monsoonal phases. During monsoons, floods submerged the point bar and deposited $\mathrm{Fm}_{\text {SILT+VFS+FS }}$ subfacies capped with a thin Fm ${ }_{\text {SILT+VFS }}(\mathrm{O})$ facies as observed at the present time. Numerous floods over a period accreted $200 \mathrm{~m}$ of over-bank deposits. The landform thus accreted bounds the southern bank of present Narmada channel.

\section{CONCLUSION}

1. High resolution quantitative granulometric record gave a large sample population to decode a suite of sediment facies, subfacies, facies association and facies transitions.

2. The plot of mean phi size and weight percentage, mean size and sorting and mean size and kurtosis indicates the mechanism of transportation of individual facies namely, $\mathrm{Fm}_{\mathrm{SILT}+\mathrm{VFS}}(\mathrm{T})$ and $\mathrm{Fm}_{\mathrm{SILT}+\mathrm{VFS}}(\mathrm{O})$ facies represents a deposition in suspension mode; $\mathrm{Fm}_{\mathrm{SILT}+\mathrm{VFS}+\mathrm{FS}}$ in both suspension and saltation mode; $\mathrm{Sl}_{\mathrm{FS}+\mathrm{VFS}}$, and $\mathrm{Sm}_{\mathrm{FS}+\mathrm{MS}}$ deposited in saltation and traction mode; and $\mathrm{St}_{\mathrm{MS}+\mathrm{FS}+\mathrm{CS}}$ and $\mathrm{St}_{\mathrm{MS}+\mathrm{CS}}$ represents deposition in traction mode.

3. The hydrodynamic conditions for the given suite of sediment facies were derived from mean/ kurtosis ratio $(\mathrm{M} / \mathrm{K}), 1 /$ kurtosis $(1 / \mathrm{K})$, standard deviation/kurtosis (S/K) along depth capturing the time line (bottom, oldest; top, youngest) suggesting changes at the time of deposition. $\mathrm{St}_{\mathrm{MS}+\mathrm{FS}+\mathrm{CS}}, \mathrm{St}_{\mathrm{MS}+\mathrm{FS}+\mathrm{CS}}$ and $\mathrm{St}_{\mathrm{MS}+\mathrm{CS}}$ were deposited in a lower elevation relative to the water level in a channel; $\mathrm{Fm}_{\mathrm{SILT}+\mathrm{VFS}}(\mathrm{T}), \mathrm{Fm}_{\mathrm{SILT}+\mathrm{VFS}}(\mathrm{O})$ and $\mathrm{Fm}_{\mathrm{SILT}+\mathrm{VFS}+\mathrm{FS}}$ facies were deposited at a relative higher elevation within the channel; and $\mathrm{Sm}_{\mathrm{FS}+\mathrm{MS}}$ and $\mathrm{Sl}_{\mathrm{FS}+\mathrm{VFS}}$ subfacies have shown a relatively intermediate elevation of the deposition.

4. Landform accretion model is suggested based on the understanding of mode of transportation and relative variation of the elevation of depositions from river channel. The study suggest seven stage multi-process evolutionarily model for aggradation of Late Holocene flood plain in LrNV.

Acknowledgements: The authors are thankful to Department of Science and Technology for the financial support through a project grant, SR/S4/ES-21/NARMADA WINDOW/P 6. PS is grateful to all student members (20062008 session) in the Sedimentological laboratory, Department of Archaeology and Ancient History, The Maharaja Sayajirao University of Baroda; especially Miss Smitha S. Kumar for all the support during different stages of the laboratory analysis. GR was supported by UGC under SAP Phase IV grant. We also wish to extend our sincere thanks to the reviewer for the suggestions. 


\section{References}

Allchin, B. and Hegde, K.T.M. (1969) The background of early man in the Narmada Valley, Gujarat: a preliminary report of the 1969 season's field work. Jour. MS Univ. Baroda, v.12, pp.141-145.

Bartholdy, J., Christiansen, C. and Pedersen, J.B.T. (2007) Comparing spatial grain-size trends inferred from textural parameters using percentile statistical parameters and those based on the log-hyperbolic method. Sedimentary Geol., v.202, pp.436-452.

Bedi, N. and VaIdYANAdHAN, R. (1982) Effect of neotectonics on the morphology of the Narmada river in Gujarat, Western India. Z. Geomorph.N.F, pp.87-102.

Bhandari, S., Maurya, D.M. and Chamyal, L.S. (2005) Late Pleistocene alluvial plain sedimentation in Lower Narmada Valley, Western India: Palaeoenvironmental implications. Jour. Asian Earth Sci., v.24, pp.433-444.

Blott, S.J. and Pye, K. (2001) Gradistat: a grain size distribution and statistics package for the analysis of unconsolidated sediments Earth Surface Processes and Landforms, v.26, pp.1237-1248.

Brandono, M., Freezza, V., Tomassetti, L., Pedley, M. and Matteucci, R. (2009) Facies analysis and palaeoenvironmental interpretation of the Late Oligocene Attard Member (Lower Coralline Limestone Formation), Malta. Sedimentology, v.56, pp.1138-1158.

Buscombe, D. and Masselink, G. (2009) Grain-size information from the statistical properties of digital images of sediment. Sedimentology, v.56, pp.421-438.

Chamyal, L.S., Khadkikar, A.S., Malik, J.N. and Maurya, D.M. (1997) Sedimentology of the Narmada alluvial fan, western India. Sedimentary Geol., v.107, pp.263-279.

Chamyal, L.S., Maurya, D.M., Bhandari, S. and RaJ, R. (2002) Late Quaternary geomorphic evolution of the lower Narmada valley, Western India: implications for neotectonic activity along the Narmada-Son Fault. Geomorphology, v.46, pp.177202.

Chamyal, L.S., and Merh, S.S. (1992) Sequence stratigraphy of the surface Quaternary deposits in the semi-arid basins of Gujarat. Man and Environment, v.17, pp.33-40.

Chamyal, L.S., Sharma, B., Merh, S.S. and Karami, H. (1994) Significance of bank material at Tilakwada in lower Narmada Valley. Curr. Sci., v.66, pp.306-307.

Cheetham, M.D., Keene, A.F., Bush, R.T., Sullivan, L.A. and Erskine, W.D. (2008) A comparison of grain-size analysis methods for sand-dominated fluvial sediments. Sedimentology, v.55, pp.1905-1913.

Citterio, A. and Piegay, H. (2009) Overbank sedimentation rates in former channel lakes: characterization and control factors. Sedimentology, v.56, pp.461-482.

Doeglas, D.J. (1968) Grain-size indices, classification and environment. Sedimentology, v.10, pp.83-100.

Folk, R.L. (1966) A review of grain-size parameters. Sedimentology, v.6, pp.73-93.

FoLK, R.L. (1974) Petrology of Sedimentary Rocks. Hemphil
Publishing Company, Austin, TX.

FolK, R.L. and WARD, W.C. (1957) Brazos River bar: a study in the significance of grain size parameters. Jour. Sediment. Petrol., v.27, pp.3-26.

Friedman, G.M., (1967) Dynamic processes and statistical parameters compared for size frequency distribution of beach and river sands. Jour. Sediment. Petrol., v.37. pp.327-354.

Friedman, G.M. and Sanders, J. (1978) Principles of Sedimentology. Wiley, New York.

Friend, P., Hirst, J. and Nichols, G. (1986) Sandstone-body structure and river process in the Ebro Basin of Aragon, Spain. Cuadernos de geología ibérica. Jour. Iberian Geol., pp.9-30.

Friend, P.F., Slater, M.J. and Williams, R.C. (1979) Vertical and lateral building of river sandstone bodies, Ebro Basin, Spain. Jour. Geol. Soc. London, v.136, pp.39-46.

Gadekar, D., Naik, S. and Sahai, B. (1981) Some aspects of geomorphic evolution of the Lower Narmada and Mahi rivers, from Landsat imagery. Recent Res. Geol., pp.32-41.

Ganapathi, S. and Pandey, A.N. (1991) Evolution of Landforms on Narmada and Tapti Estuarine Deltas, Gujarat Quaternary Deltas of India, pp.103.

Goossens, D. (2008) Techniques to measure grain-size distributions of loamy sediments: a comparative study of ten instruments for wet analysis. Sedimentology, v.55, pp.65-96.

Guerzoni, S., Portaro, R., Trincardi, F., Molinaroli, E., Langone L., et al. (1996) Statistical analyses of grain-size, geochemical and mineralogical data in core CM92-43, Central Adriatic basin. Mem. Ist. ital. Idrobiol, v.55, pp.231-245.

Hajek, E.A., Huzurbazar, S. V., Mohrig, D., Lynds, R.M. and Heller, P.L. (2010) Statistical Characterization of Grain-Size Distributions in Sandy Fluvial Systems. Jour. Sediment. Res., v.80, pp.184-192.

JACKSON, R.G. (1975) Hierarchical attributes and a unifying model of bed forms composed of cohesionless material and produced by shearing flow. Bull. Geol. Soc. Amer., v.86, pp.1523.

Knox, J.C. (2000) Sensitivity of modern and Holocene floods to climate change. Quaternary Sci. Rev., v.19, pp.439-457.

KrumbeIN, W.C. (1934) Size frequency distribution of sediments. Jour. Sediment. Petrol., v.4, pp.65-77.

Macklin, M.G., Fuller, I.C., Lewin, J., Maas, G.S., Passmore, D.G., et al. (2002) Correlation of fluvial sequences in the Mediterranean basin over the last $200 \mathrm{ka}$ and their relationship to climate change. Quaternary Sci. Rev., v.21, pp.1633-1641.

MackLIN, M.G., and Lewin, J. (2003) River sediments, great floods and centennial-scale Holocene climate change. Jour. Quaternary Sci., v.18, pp.101-105.

Martinius, A.W. (2000) Labyrinthine Facies Architecture of the Tortola Fluvial System and Controls on Deposition (Late Oligocene-Early Miocene, Loranca Basin, Spain). Jour. Sedimentary Res., v.70, pp.850-867.

Martins, L.R. (1965) Significance of skewness and kurtosis in environmental interpretation. Jour. Sediment. Res., v.35, pp.768.

Miall, A. (1978) Lithofacies types and vertical profile models in 
braided river deposits: a summary. Fluvial Sedimentology, v.5, pp.597-604.

Miall, A.D. (1985) Architectural-element analysis: a new method of facies analysis applied to fluvial deposits. Earth Sci. Rev., v.22, pp.261-308.

Nanson, G., and Tоотн, S. (1999) Arid-zone rivers as indicators of climate change. Paleoenvironmental reconstruction in arid lands. Oxford and IBH, New Delhi and Calcutta, pp.75-216.

Oldfield, F., Hao, Q., Bloemendal, J.A.N., Gibbs-Eggar, Z., Patil S., et al. (2009) Links between bulk sediment particle size and magnetic grain-size: general observations and implications for Chinese loess studies. Sedimentology, v.56, pp.2091-2106.

Pandey, S.K., Singh, A.K. and Hasnain, S.I. (2002) Grain-size distribution, morphoscopy and elemental chemistry of suspended sediments of Pindari Glacier, Kumaon Himalaya, India. Hydrological Sci. Jour., v.47, pp.213-226.

Passega, R. (1964) Grain size representation by CM patterns as a geologic tool. Jour. Sediment. Res., v.34, pp.830.

Poizot, E., Méar, Y. and Biscara, L. (2008) Sediment Trend Analysis through the variation of granulometric parameters: A review of theories and applications. Earth Sci. Rev., v.86, pp.15-41.

PurkaIT, B. (2006) Grain-size distribution patterns of a point bar system in the Usri River, India. Earth Surface Processes and Landforms, v.31, pp.682-702.

RAJ, R. (2007) Late Pleistocene fluvial sedimentary facies, the Dhadhar River basin, Western India. Quaternary Internat., v.159, pp.93-101.

RAJ, R. (2008) Occurrence of volcanic ash in the Quaternary alluvial deposits, lower Narmada basin, western India. Jour. Earth System Sci., v.117, pp.41-48.

RaJ, R., Bhandari, S., Maurya, D.M. and Chamyal, L. S. (2003) Geomorphic Indicators of Active Tectonics in the Karjan River Basin, Lower Narmada Valley, Western India. Jour. Geol. Soc. India, v.62, pp.739-752.

RAJ, R. and YADAVA, M.G. (2009) Late Holocene uplift in the lower Narmada basin, western India. Curr. Sci., v.96, pp.985-988.

Reid, I. and Frostick, L. (1997) Channel form, flows and sediments in deserts. Arid zone geomorphology: Process, form and change in drylands, pp.205-229.

Ren, J. and Packman, A.I. (2007) Changes in fine sediment size distributions due to interactions with streambed sediments. Sedimentary Geol., v.202, pp.529-537.
Richard, G.A., Julien, P.Y. and BAIRD, D.C. (2005) Statistical analysis of lateral migration of the Rio Grande, New Mexico. Geomorphology, v.71, pp.139-155.

SAHU, B.K. (1964) Depositional mechanisms from the size analysis of clastic sediments. Jour. Sediment. Petrol., v.34, pp.73-83.

SANT, D.A. (1991) Structure and Geomorphic evolution of the Lower Narmada Valley in Western India. Unpubl, Ph. D. Thesis, the Maharaja Sayajrao University, Vadodara, 228p.

SANT, D.A. (1999) Landscape, Structure and Morphological Development of Saurashtra Peninsula and Lower Narmada Valley, Western India. Mem. Geol. Soc. of India, no.43, pp.335-352.

SANT, D.A. and Karanth, R.V. (1988) Morphological Parameters and their Correlation with Litology and Structure of the Area betwen Uchh Nadi and Narmada River in Central Gujarat. Navnirman, v.19, pp.17-28.

SAnt, D.A. and Karanth, R.V. (1993) Drainage evolution of the lower Narmada valley, western India Geomorphology, v.8, pp.221-244.

Sukumaran, P., Parvez, I.A., Sant, D.A., Rangarajan, G. and Krishnan, K. (2011) Profiling of Late Tertiary - Early Quaternary surface in the lower reaches of Narmada valley using Microtremors. Jour. Asian Earth Sci., v.41(3), pp.325334.

Sukumaran, P., Rajshekhar, C., Sant, D.A. and Krishnan, K. (Accepted) Late Holocene Storm Records from Lower Reaches of Narmada Valley, western India. Jour. Geol. Soc. India, v.79,

Syvitski, J.P. (Ed.) (2007) Principles, methods, and application of particle size analysis. Cambridge University Press.

Tenner, W. F. (2007a) Application of suite statistics to stratigraphy and sea-level. In: J.P. Syvitski (Ed.), Principle, mehods, and application of particle Size Analysis. Cambridge University Press, Cambridge, New York, pp.283-292.

Tenner, W.F. (2007b). Suite statistics: The hudrodynamic evolution of the sediment pool. In: J.P. Syvitski (Ed.), Principle, mehods, and application of particle Size Analysis. Cambridge University Press, Cambridge, New York, pp.225-236.

Visher, G.S. (1969) Grain size distributions and depositional processes. Jour. Sediment. Petrol., v.39, pp.1074-1106.

Wainwright, G. (1964) The Pleistocene Deposits of the Lower Narmada River and an Early Stone Age Industry from the River Chambal. The Maharaja Sayajirao University of Baroda, Dept. Archaeology and Ancient History, Series 7, Baroda, India. 